\title{
PENGARUH KECERDASAN INTELEKTUAL, DAN KECERDASAN EMOSIONAL TERHADAP KINERJA PELAKU USAHA KECIL DI KOTA BANDUNG
}

\author{
Harun Heri Trismiyanto, Iwan Ardiansyah \\ harundnbs@gmail.com iwanardiansyah8054@yahoo.com \\ Program Studi Manajemen, Fakultas Ekonomi, Universitas Al-Ghifari
}

\begin{abstract}
Future uncertainty that can occur in financial services companies is a risk that Small industries in the city of Bandung play a very important role and contribute to the economy in the city of Bandung and nationally. For this reason, it is necessary to have high performance so that it can compete both in the national market and in the global market.

This study aims to identify external and internal factors that determine the influence of intellectual, intelligence and emotional intelligence on the performance of small business actors on handicraft products in Bandung City. Small industries are still constrained by various internal and external factors. Internal factors include aspects of human resources and capital, marketing and design, while external factors include market conditions, availability of raw materials and government policies.

Types of data are secondary data obtained from various related literatures. The sample in this study amounted to 50 business actors.

Small entrepreneurs must maintain the implementation of the important factors that determine the performance of their business, while still making improvements to the factors that are still not being implemented, in order to get better performance.

Keywords: Intellectual and Emotional Intelligence on the Performance of Small Business Owners in Bandung
\end{abstract}

\section{Pendahuluan}

Era globalisasi telah menjadikan dunia usaha semakin dituntut untuk dapat menunjukan kepiawaiannya dalam menjalankan usahanya. Kondisi ini tentu tidak terlepas dari adanya peran sumber daya terutama daya manusia. Saat ini sumber daya manusia dihadapkan kepada tuntutan perusahaan akan perlunya peningkatan yang lebih dari sebelumnya berkaitan dengan kinerja. Permasalahan mengenai kinerja merupakan permasalahan yang akan 
selalu dihadapi oleh setiap perusahaan. Oleh karena itu untuk mengatasi permasalahan ini, perusahaan perlu sekali mengetahui faktor-faktor yang dapat mempengaruhi kinerja. Kecerdasan diatas sangatlah mendukung peningkatan kinerja sebuah perusahaan tidak terkecuali juga pada industri kreatif yang akhir-akhir ini menjadi topik hangat sebagian besar masyarakat indonesia. Kreatif lebih bertumpu pada kualitas sumber daya manusia. Industri kreatif justru lebih banyak muncul dari kelompok industri kecil menengah.

Usaha kecil di Kota Bandung sebagai kegiatan ekonomi yang benarbenar mencerminkan potensi dan produktivitas sumberdaya lokal, memainkan peran penting dalam menciptakan nilai tambah melalui keberadaan produk atau jasa kreatif. Industri kreatif Indonesia telah menjadi salah satu yang paling sukses dan dan industri menjanjikan sejak tahun 2002'. Rata-rata kontribusi PDB industri kreatif indonesia tahun 2002-2015 sebesar 3,6\% dari total PDB Nasional dengan nilai Rp.104,6 trilyun. Nilai ekspor industri kreatif mencapai Rp.81,4 trilyun dan berkontribusi sebesar 9,13\% terhadap total nilai ekspor nasional dengan penyerapan tenaga kerja mencapai 5,4 juta pekerja.

Industri usaha kecil ini tidak pernah mati karena menjadi bagian dari budaya masyarakat. Namun, tidak mampu tumbuh secara pesat karena belum ada sentuhan serius dari pemerintah. Kondisi industri kreatif khususnya usaha kecil di Kota Bandung tergolong cukup baik perkembangannya, namun masih kurang dalam hal kreativitas serta ide-ide baru yang berkenaan dengan produk. Ini terlihat dari kurangnya variasi atau keberagaman dalam hal desain. Selain itu jumlah yang dihasilkan pun masih dalam jumlah yang terbatas. Penting kiranya untuk mendorong kemampuan masyarakat agar dapat berkreasi dan menjadi bagian dari sektor industri kreatif.

Kinerja yang masih rendah dari para pelaku usaha ini perlu mendapat perhatian dari berbagai pihak dan perlu dilakukan penelitian lebih mendalam faktor penyebabnya, karena seperti halnya kondisi yang ditemukan dilapangan berdasarkan wawancara dengan pelaku usaha kecil ditemukan fakta bahwa mereka melakukan usaha atas dorongan memenuhi kebutuhan hidup saja belum terfikirkan untuk dapat mengembangkan 
kearah yang lebih serius untuk dapat layaknya sebuah perusahaan besar. Kondisi ini diperkuat dengan masih kurangnya pemahaman dan ketrampilan yang mereka miliki tentang produk yang dihasilkan.Ini terlihat dari kurangnya akses informasi pasar dan peluang pasar, pemahaman mengenai data base dan bursa produk yang masih terbatas, serta pemahaman mengenai cashflow yang masih rendah. Pemahaman yang dimiliki oleh pelaku usaha ini dipengaruhi oleh pengetahuan yang didapatkan secara formal maupun informal masih sangat rendah. Artinya dapat diduga kecerdasan intelektual yang dimiliki para pelaku usaha masih rendah.

Karenanya yang penting perlu diperhatikan untuk mendorong tumbuhnya budaya kreatif. Pertama, pemanfaatan internet dan saluran informasi untuk dapat memetik dan mempelajari kreativitas dunia. Kedua menciptakan pasar domestik dan pasar ekspor yang menyerap berbagai produk kreatif ini. Ketiga dengan cara menggandeng komunitas kreatif. Adanya keinginan untuk memenuhi kebutuhan hidup dari pelaku usaha mendorong mereka untuk dapat terus bertahan dalam industri kreatif ini, namun tidak cukup dengan sekedar keinginan dalam menghadapi persaingan yang semakin tinggi seperti saat ini. Dibutuhkan semangat, ketekunan serta kemampuan untuk dapat memotivasi diri sendiri dan keinginan kuat untuk terus belajar sehingga mampu mengembangkan dan melakukan kreativitas yang tinggi. Masih rendahnya semangat untuk belajar membuat kecakapan hasil belajar yang dihasilkanpun akan rendah sehinggga diduga kecerdasan emosional yang dimiliki para pelaku usaha masih rendah.

\section{Tinjauan Teori}

Intelektual adalah kemampuan kognitif yang dimiliki organisme untuk menyesuaikan diri secara efektif pada lingkungan yang kompleks dan selalu berubah serta dipengaruhi oleh faktor genetik (Galton, dalam Joseph, 1978: 20). Menurut Robbins (2001:57), kemampuan intelektual adalah kemampuan yang diperlukan untuk menjalankan kegiatan mental, berpikir, menalar dan memecahkan masalah. Menurut William Stren dalam Purwanto, (2003:52), Kecerdasan intelektual adalah kesanggupan 
untuk menyesuaikan diri kepada kebutuhan baru, dengan menggunakan alat-alat berfikir yang sesuai dengan tujuan. Wechler dalam Pratiwi (2011) merumuskan kecerdasan intelektual sebagai keseluruhan kemampuan individu untuk berpikir dan bertindak secara terarah serta kemampuan mengelola dan meguasai lingkungan secara efektif.

Dari beberapa definisi diatas, kecerdasan intelektual merupakan keseluruhan kemampuan dan kesanggupan seseorang untuk menjalankan kegiatan mental, berpikir, bertindak secara terarah dan memecahkan masalah dengan menggunakan alat-alat berfikir yang sesuai dengan tujuan dalam rangka untuk menyesuaikan diri kepada kebutuhan baru.

Salovey (Goleman, 2009:57), menempatkan kecerdasan pribadi dari Gardner sebagai definisi dasar dari kecerdasan emosional. Kecerdasan yang dimaksud adalah kecerdasan antar pribadi dan kecerdasan intrapribadi. Salovey dan Mayer dalam (Shapiro, 2006:42) mendefinisikan kecerdasan emosional atau yang sering disebut EQ sebagai : "himpunan bagian dari kecerdasan sosial yang melibatkan kemampuan memantau perasaan sosial yang melibatkan kemampuan pada orang lain, memilahmilah semuanya dan menggunakan informasi ini untuk membimbing pikiran dan tindakan."

Seorang ahli kecerdasan emosional, Goleman (2000:13) mengatakan bahwa yang dimaksud dengan kecerdasan emosi di dalamnya termasuk kemampuan mengontrol diri, memacu, tetap tekun, serta dapat memotivasi diri sendiri. Kecerdasan emosional sangat dipengaruhi oleh lingkungan, tidak bersifat menetap, dapat berubah-ubah setiap saat. Untuk itu peranan lingkungan terutama orang tua pada masa kanak-kanak sangat mempengaruhi dalam pembentukan kecerdasan emosional. Cooper dan Sawaf (1998) dalam Rachmi (2010) mendefinisikan kecerdasan emosional sebagai kemampuan merasakan, memahami, dan secara efektif menerapkan daya dan kepekaan emosi sebagai sumber energi, informasi, koneksi dan pengaruh yang manusiawi.

Dari beberapa pendapat di atas dapatlah dikatakan bahwa kecerdasan emosional merupakan kemampuan mengenali perasaan kita sendiri dan perasaan orang lain yang kemudian dengan informasi ini berguna untuk membimbing pikiran dan tindakan." 


\section{Motodelogi}

Metode yang digunakan dalam penelitian ini adalah metode deskriptif dan verifikatif dengan pendekatan kuantitatif, metode ini digunakan karena penulis ingin mendeskripsikan Kecerdasan Intelektual, Kecerdasan Terhadap Kinerja Pemilik Usaha Kecil Di Kota Bandung.

Metode yang digunakan dalam penelitian ini adalah metode survei yaitu penelitian yang mengambil sampel dari populasi dan menggunakan kuesioner sebagai alat pengumpulan data. Desain penelitian ini menggunakan pendekatan paradigma hubungan antara tiga variabel bebas secara bersamaan yang mempunyai hubungan dengan satu variabel tergantung.

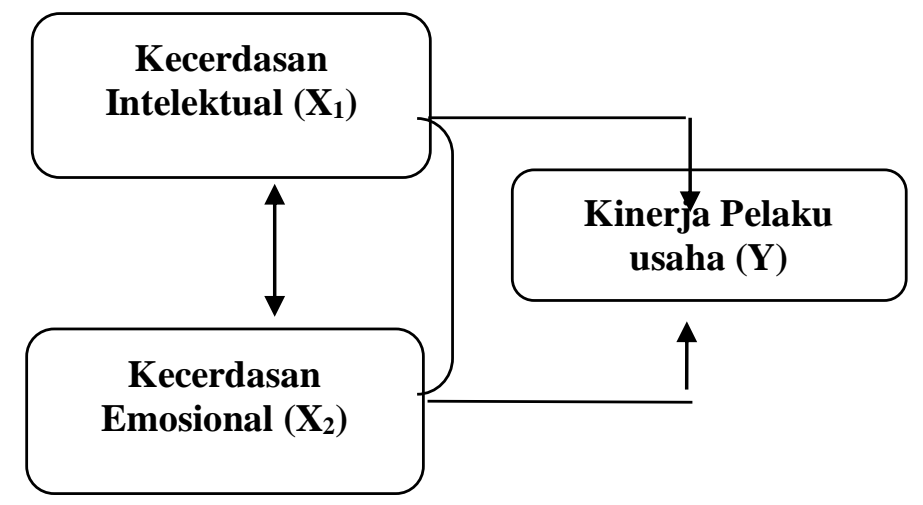

Adapun operasionalisasi variabel dalam penelitian ini secara lebih jelas dapat dilihat pada tabel 3.1 berikut ini :

Tabel 3

Operasionalisasi Variabel

\begin{tabular}{|c|c|c|c|c|}
\hline Variabel & Konsep Variabel & Indikator & Skala & $\begin{array}{c}\text { Sumber } \\
\text { Data }\end{array}$ \\
\hline
\end{tabular}




\begin{tabular}{|c|c|c|c|c|}
\hline $\begin{array}{l}\text { Kecerdasan } \\
\text { Intelektual } \\
\left(\mathrm{X}_{1}\right)\end{array}$ & $\begin{array}{l}\text { Kemampuan } \text { intelektual, } \\
\text { analisa, logika, dan rasio. } \\
\text { Kecerdasan } \\
\text { merupakan kecerdasan } \\
\text { untuk menerima, } \\
\text { menyimpan, } \\
\text { mengolah informasi } \\
\text { menj adi fakta } \\
\text { (Widodo, 2012, p. 77) }\end{array}$ & $\begin{array}{l}\text { 1. Mudah dalam } \\
\text { menggunakan hitungan } \\
\text { 2. Baik ingatan } \\
\text { 3. Mudah menangkap } \\
\text { hubungan percakapan- } \\
\text { percakapan } \\
\text { 4. Mudah menarik } \\
\text { kesimpulan } \\
\text { 5. Cepat dalam mengamati } \\
\text { 6. Cakap dalam } \\
\text { memecahkan berbagai } \\
\text { problem } \\
\text { Mujib dan Mudzakir (2000) }\end{array}$ & Ordinal & $\begin{array}{l}\text { Pelaku } \\
\text { Usaha } \\
\text { Kecil } \\
\text { Kerajina } \\
\text { n Jawa } \\
\text { Barat }\end{array}$ \\
\hline
\end{tabular}

\begin{tabular}{|c|c|c|c|c|}
\hline $\begin{array}{l}\text { Kecerdasan } \\
\text { Emosional } \\
\left(\mathbf{X}_{2}\right)\end{array}$ & $\begin{array}{l}\text { Kecerdasan emosional } \\
\text { merujuk kepada } \\
\text { kemampuan mengenali } \\
\text { perasaan diri sendiri dan } \\
\text { orang lain, kemampuan } \\
\text { memotivasi diri sendiri, } \\
\text { dan kemampuan } \\
\text { mengelola emosi dengan } \\
\text { baik pada diri sendiri } \\
\text { dalam hubungan dengan } \\
\text { orang lain. } \\
\text { (Goleman, 2000) }\end{array}$ & $\begin{array}{l}\text { 1. Self awareness } \\
\text { 2. Self management } \\
\text { 3. Motivation } \\
\text { 4. Empati (social } \\
\text { awareness) } \\
\text { 5. Relationship } \\
\text { management } \\
\text { Goleman,(2000,pp.42-43) }\end{array}$ & Ordinal & $\begin{array}{l}\text { Pelaku } \\
\text { Usaha } \\
\text { Kecil } \\
\text { Kerajina } \\
\text { n Jawa } \\
\text { Barat }\end{array}$ \\
\hline $\begin{array}{l}\text { Kinerja } \\
\text { (Y) }\end{array}$ & $\begin{array}{l}\text { suatu konsep yang } \\
\text { bersifat universal yang } \\
\text { merupakan efektifitas } \\
\text { operasional suatu } \\
\text { organisasi, bagian } \\
\text { organisasi, dan } \\
\text { karyawannya } \\
\text { berdasarkan standar dan } \\
\text { kriteria yang telah } \\
\text { ditetapkan sebelumnya. } \\
\text { Maksud dan tujuan } \\
\text { kinerja adalah } \\
\text { menyusun sasaran yang } \\
\text { berguna, tidak hanya } \\
\text { bagi evaluasi kinerja } \\
\text { pada akhir periode } \\
\text { tertentu, melainkan } \\
\text { hasil proses kerja } \\
\text { sepanjang periode }\end{array}$ & $\begin{array}{l}\text { 1. Kualitas } \\
\text { 2. Kuantitas } \\
\text { 3. Ketepatan waktu } \\
\text { 4. Efektifitas } \\
\text { 5. Kemandirian } \\
\text { 6. Komitmen }\end{array}$ & Ordinal & $\begin{array}{l}\text { Pelaku } \\
\text { Usaha } \\
\text { Kecil } \\
\text { Kerajina } \\
\text { n Jawa } \\
\text { Barat }\end{array}$ \\
\hline
\end{tabular}




\begin{tabular}{|l|l|l|l|l|}
\hline & $\begin{array}{l}\text { tersebut } \\
\text { (Simamora, 2007, p. } \\
\text { 56). }\end{array}$ & & & \\
\end{tabular}

\section{Teknik Penentuan Data}

\section{Populasi}

Menurut Sugiyono (2008:80), pengertian populasi adalah sebagai berikut:

"Populasi adalah wilayah generalisasi yang terdiri atas objek atau subjek yang mempunyai kuantitas dan karakteristik tertentu yang ditetapkan oleh peneliti untuk dipelajari dan kemudian ditarik kesimpulannya".

Berdasarkan pengertian tersebut maka populasi dalam penelitian ini adalah seluruh pelaku usaha kecil kerajinan di Jawa Barat.

Berikut ini data Usaha Kecil di Provinsi Jawa Barat:

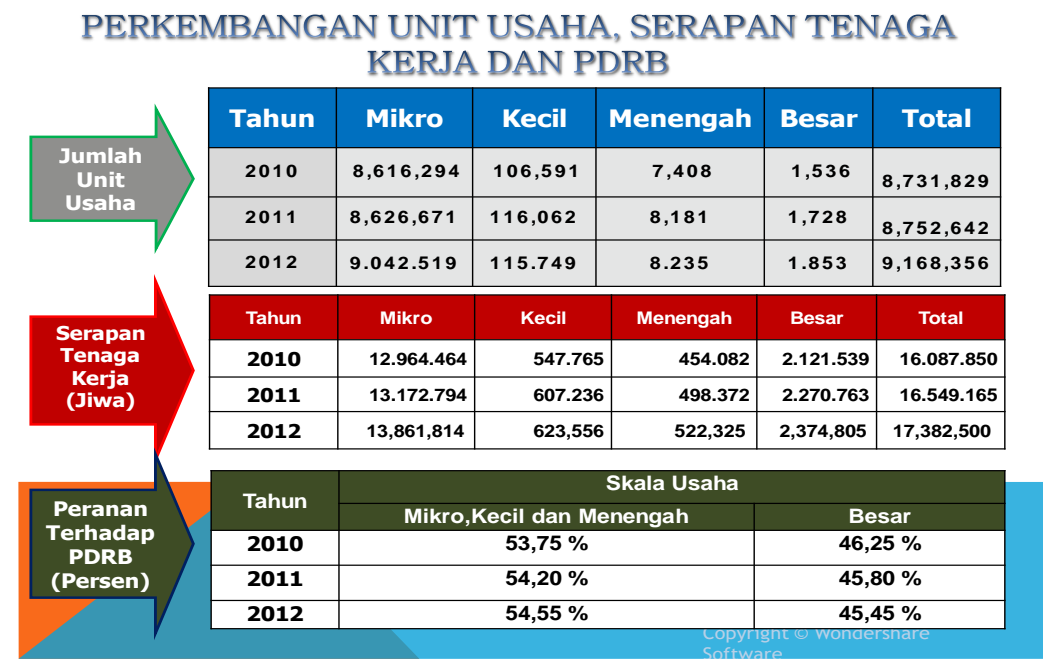

Sumber : Dinas Koperasi dan KUMKM Provinsi Jawa Barat

\section{TAIU PERTUMBUHAN UMMMI JAWA BARAT}

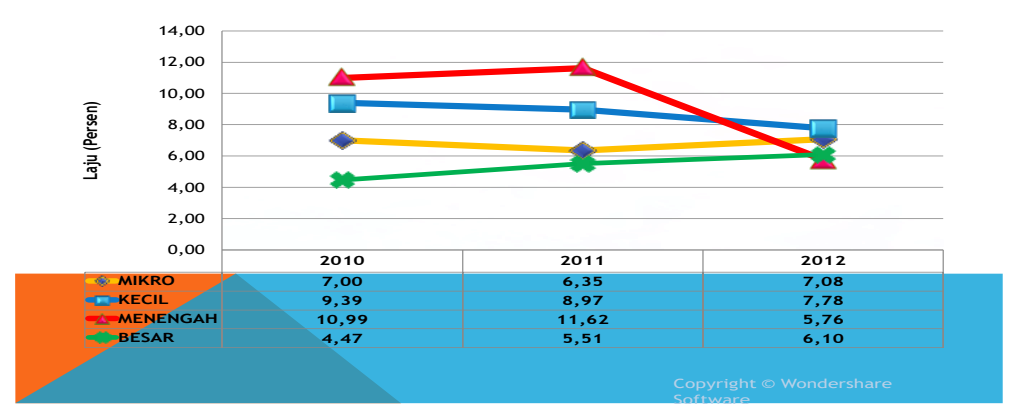


UMKM

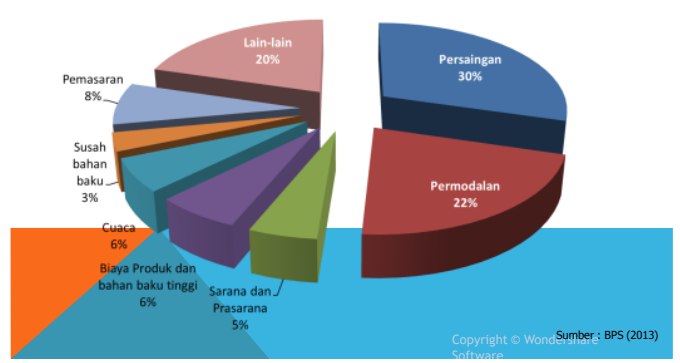

\section{Sampel}

Metode penarikan sampel yang digunakan dalam penelitian ini mengacu kepada pendekatan Solvin, pendekatan ini dinyatakan dengan rumus sebagai berikut :

$$
n=\frac{N}{1+N e^{2}}
$$

Ket :

$\mathrm{n}=$ jumlah sampel

$\mathrm{N}=$ jumlah populasi $\mathrm{e}=$ tingkat kesalahan dalam penelitian $10 \%$ atau 0,1

\section{Hasil Dan Pembahasan}

Hasil Pengolahan Data

Uji Normalitas 


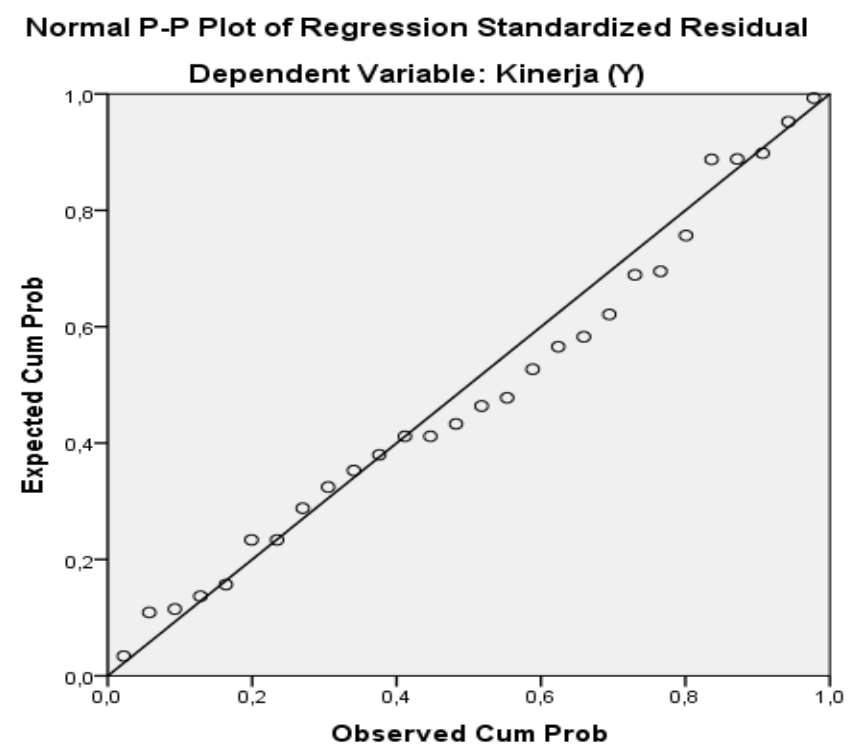

Interpretasi Hasil:

Dari Normal P-P Plot of Regression Standardized Residual untuk dependent variable: Kinerja di atas menunjukan bahwa Model Regresi berdistribusi normal karena titik-titik menyebar di sekitar diagonal serta menyebar mengikuti arah diagonal. Hal ini menunjukan bahwa data Kinerja berdistribusi normal.

\section{Uji Multikolinearitas}

Coefficients $^{\mathbf{a}}$

\begin{tabular}{|c|c|c|c|c|c|c|c|}
\hline \multirow[t]{2}{*}{ Model } & \multicolumn{2}{|c|}{$\begin{array}{l}\text { Unstandardized } \\
\text { Coefficients }\end{array}$} & \multirow{2}{*}{$\begin{array}{c}\begin{array}{c}\text { Standardized } \\
\text { Coefficients }\end{array} \\
\text { Beta }\end{array}$} & \multirow[t]{2}{*}{$\mathrm{t}$} & \multirow[t]{2}{*}{ Sig. } & \multicolumn{2}{|c|}{$\begin{array}{c}\text { Collinearity } \\
\text { Statistics }\end{array}$} \\
\hline & B & Std. Error & & & & Tolerance & VIF \\
\hline (Constant) & 7,758 & 6,650 & & 1,167 &, 254 & & \\
\hline $\begin{array}{ll} & \text { Kecerdasan } \\
1 & \text { Intelektual (X1) }\end{array}$ & ,765 & ,377 & ,454 & 2,030 & ,053 & ,234 & 4,268 \\
\hline $\begin{array}{l}\text { Kecerdasan } \\
\text { Emosional (X2) }\end{array}$ & ,454 &, 244 & ,415 & 1,857 & ,075 & ,234 & 4,268 \\
\hline
\end{tabular}

a. Dependent Variable: Kinerja (Y)

Interpretasi Hasil:

Untuk mengetahui apakah telah terjadi Multikolinearitas dapat dilihat dari nilai tolerance atau VIF. Kedua ukuran menunjukan setiap variable bebas dijelaskan variable bebas lainnya. Suatu model regresi dikatakan bebas dari 
Multikolinearitas apabila nilai tolerance lebih besar dari 0.1 atau VIF lebih kecil dari 10.

Hasil uji Multikolinearitas di atas menunjukan bahwa tidak terdapat variable bebas yang memiliki nilai tolerance kurang dari 0.1 dan VIF lebih dari 10. Jadi dapat disimpulkan bahwa persamaan model regresi yang diolah bebas dari Multikolinearitas.

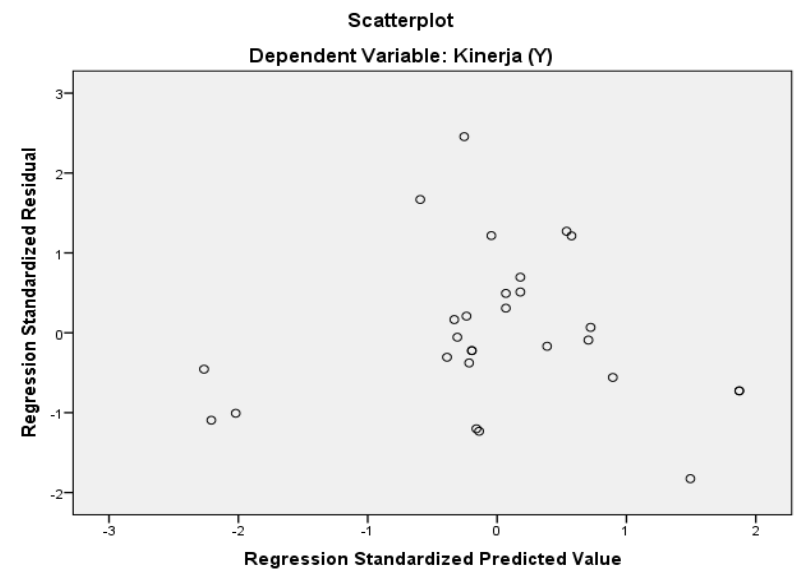

Interpretasi Hasil:

Pada grafik tersebut terlihat bahwa tidak terdapat pola yang jelas karena titik-titik menyebar di atas dan di bawah angka nol pada sumbu Y. Hal ini dapat disimpulkan bahwa tidak terdapat heteroskedastisitas pada model regresi.

\section{Uji Autokorelasi}

Model Summary ${ }^{\mathbf{b}}$

\begin{tabular}{|l|r|r|r|r|r|}
\hline Model & R & R Square & Adjusted R Square & $\begin{array}{c}\text { Std. Error of the } \\
\text { Estimate }\end{array}$ & Durbin-Watson \\
\hline 1 &, $841^{\mathrm{a}}$ &, 707 &, 684 & 5,405 & 1,964 \\
\hline
\end{tabular}

a. Predictors: (Constant), Kecerdasan Emosional (X2), Kecerdasan Intelektual (X1)

b. Dependent Variable: Kinerja (Y)

Interpretasi Hasil:

Nilai Durbin-Watson yang diperoleh dari hasil pengolahan data sebesar 1.964. nilai tersebut lebih besar dari satu dan lebih kecil dari empat, maka 
residual atau eror model regresi berganda bersifat bebas atau tidak terjadi autokorelasi.

Jadi model regresi linear tidak terdapat korelasi antara kesalahan pengganggu pada periode sekarang dengan kesalahan pengganggu periode sebelumnya.

Analisis Persamaan Regresi Linear Berganda

Coefficients $^{\mathrm{a}}$

\begin{tabular}{|c|c|c|c|c|c|c|c|}
\hline \multirow[t]{2}{*}{ Model } & \multicolumn{2}{|c|}{$\begin{array}{l}\text { Unstandardized } \\
\text { Coefficients }\end{array}$} & \multirow{2}{*}{$\begin{array}{c}\begin{array}{c}\text { Standardize } \\
\text { d } \\
\text { Coefficients }\end{array} \\
\text { Beta }\end{array}$} & \multirow[t]{2}{*}{$\mathrm{t}$} & \multirow[t]{2}{*}{ Sig. } & \multicolumn{2}{|c|}{$\begin{array}{l}\text { Collinearity } \\
\text { Statistics }\end{array}$} \\
\hline & B & Std. Error & & & & $\begin{array}{c}\text { Toleranc } \\
\mathrm{e}\end{array}$ & VIF \\
\hline (Constant) & 7,758 & 6,650 & & 1,167 &, 254 & & \\
\hline $\begin{array}{l}\text { Kecerdasan Intelektual } \\
1 \text { (X1) }\end{array}$ & ,765 & 377 & 454 & 2,030 & ,053 & ,234 & 4,268 \\
\hline $\begin{array}{l}\text { Kecerdasan Emosional } \\
\text { (X2) }\end{array}$ & 454 & ,244 & ,415 & 1,857 & ,075 & ,234 & 4,268 \\
\hline
\end{tabular}

a. Dependent Variable: Kinerja (Y)

Persamaan regresi berganda yang diperoleh adalah:

$\mathrm{Y}=7.758+0.765 \times 1+0.454 \times 2$

Dimana $\mathrm{Y}=$ Kinerja, $\mathrm{X} 1=$ Kecerdasan Intelektual, $\mathrm{X} 2=$ Kecerdasan Emosional.

a. Dari table di atas diketahui hubungan antara variable Kecerdasan Intelektual dengan Kinerja berbanding lurus atau positif.

b. variable Kecerdasan Emosional dengan Kinerja berbanding lurus atau positif.

\section{Analisis Korelasi Berganda}

\begin{tabular}{|l|r|r|r|r|r|}
\hline Model & $\mathrm{R}$ & R Square & $\begin{array}{c}\text { Adjusted R } \\
\text { Square }\end{array}$ & $\begin{array}{c}\text { Std. Error of the } \\
\text { Estimate }\end{array}$ & Durbin-Watson \\
\hline 1 &, $841^{\mathrm{a}}$ &, 707 &, 684 & 5,405 & 1,964 \\
\hline
\end{tabular}

a. Predictors: (Constant), Kecerdasan Emosional (X2), Kecerdasan Intelektual (X1)

b. Dependent Variable: Kinerja (Y)

Nilai Adjusted $R$ Square dari table model summary menunjukan $68.4 \%$ dari variance "Kinerja" dapat dijelaskan oleh perubahan dalam variable "Kecerdasan emosional" dan "Kecerdasan intelektual", sedangkan sisanya 
sebesar (100\%-68.4\%) 31.6\% dijelaskan oleh faktor (variable) lain dari luar model

\section{Uji Simultan (Uji F)}

\begin{tabular}{|l|r|r|r|r|r|}
\hline Model & Sum of Squares & df & Mean Square & F & \multicolumn{1}{c|}{ Sig. } \\
\hline Regression & 1766,391 & 2 & 883,195 & 30,233 &, $000^{\mathrm{b}}$ \\
Residual & 730,324 & 25 & 29,213 & & \\
Total & 2496,714 & 27 & & & \\
\hline
\end{tabular}

a. Dependent Variable: Kinerja (Y)

b. Predictors: (Constant), Kecerdasan Emosional (X2), Kecerdasan Intelektual (X1)

\section{Hipotesis:}

$\mathrm{H}_{0}$ : Kecerdasan Intelektual dan kecerdasan emosional tidak berpengaruh secara simultan terhadap kinerja.

$\mathrm{H}_{1}$ : Kecerdasan Intelektual dan

kecerdasan emosional berpengaruh secara simultan terhadap kinerja.

Interpretasi Hasil:

Nilai sig. yang menunjukan nilai sebesar 0.000 lebih kecil dibandingkan tingkat signifikan 0.05, sehingga dapat disimpulkan bahwa kecerdasan intelektual dan kecerdasan emosional berpengaruh secara simultan terhadap variable kinerja.

\section{Uji Parsial (Uji t)}

\section{Coefficients $^{\mathrm{a}}$}

\begin{tabular}{|c|c|c|c|c|c|c|c|}
\hline \multirow[t]{2}{*}{ Model } & \multicolumn{2}{|c|}{$\begin{array}{l}\text { Unstandardized } \\
\text { Coefficients }\end{array}$} & \multirow{2}{*}{$\begin{array}{c}\text { Standardiz } \\
\text { ed } \\
\text { Coefficient } \\
\text { s } \\
\text { Beta }\end{array}$} & \multirow[t]{2}{*}{$\mathrm{t}$} & \multirow[t]{2}{*}{ Sig. } & \multicolumn{2}{|c|}{$\begin{array}{l}\text { Collinearity } \\
\text { Statistics }\end{array}$} \\
\hline & $\mathrm{B}$ & Std. Error & & & & $\begin{array}{c}\text { Toleran } \\
\text { ce }\end{array}$ & VIF \\
\hline (Constant) & 7,758 & 6,650 & & 1,167 & ,254 & & \\
\hline $\begin{array}{l}\text { Kecerdasan } \\
\text { Intelektual (X1) }\end{array}$ & ,765 & 377 & 454 & 2,030 & ,053 & 234 & 4,268 \\
\hline $\begin{array}{l}\text { Kecerdasan } \\
\text { Emosional (X2) }\end{array}$ & ,454 & 244 & ,415 & 1,857 & ,075 & ,234 & 4,268 \\
\hline
\end{tabular}

a. Dependent Variable: Kinerja (Y)

Hipotesis: 
$\mathrm{H} 2$ : kecerdasan intelektual berpengaruh secara signifikan terhadap kinerja H3: kecerdasan emosional berpengaruh secara signifikan terhadap kinerja

Interpretasi Hasil:

Melihat Nilai sig. yang menunjukan nilai untuk Kecerdasan Intelektual sebesar 0.053 lebih kecil dibandingkan tingkat signifikan 0.05, sehingga dapat disimpulkan bahwa kecerdasan intelektual tidak berpengaruh positif terhadap variable kinerja.

Melihat Nilai sig. yang menunjukan nilai untuk pengalaman kerja sebesar 0.013 lebih kecil dibandingkan tingkat signifikan 0.05 , sehingga dapat disimpulkan bahwa kecerdasan emosional berpengaruh terhadap variable kinerja dan hipotesis tidak dapat ditolak.

\section{Kesimpulan}

1. Kecerdasan intelektual dan kecerdasan emosional seseorang berpengaruh secara simultan terhadap kinerja.

2. Kecerdasan intelektual seseorang berpengaruh secara signifikan terhadap kinerja.

3. Kecerdasan emosional seseorang berpengaruh secara simultan terhadap kinerja.

4. kecerdasan intelektual seseorang tidak berpengaruh positif terhadap variable kinerja.

5. Kecerdasan emosional seseorang berpengaruh positif terhadap kinerja.

\section{Saran}

Untuk penelitian mendatang hendaknya lebih memperdalam instrumen penelitian serta mengembangkannya lagi sehingga pengukurannya lebih baik. Dari hasil penelitian ini menunjukkan bahwa masih banyak variabel-variabel lain yang mempengaruhi prestasi kinerja yang perlu diteliti, karena berdasarkan hasil penelitian setelah menggunakan variabel moderasi menunjukkan adanya peningkatan terhadap kinerja, akan tetapi masih belum maksimal.

Hal tersebut menunjukkan bahwa masih ada variabel bebas lain yang akan mempengaruhi kinerja. Peneliti menyarankan untuk penelitian yang akan datang agar dilakukan penelitian diobjek yang sama dan 
menambahkan sebuah variabel yang akan mendukung keberhasilan kinerja seperti menambahkan sebuah variabel moderasi atau intervening misalnya motivasi kerja, disiplin kerja, usia dan lain-lain, sehingga dapat memberikan gambaran yang lebih lengkap lagi akan pengaruh ketiga variabel independen terhadap variabel dependen secara tidak langsung.

\section{Daftar Pustaka}

Ary Ginanjar Agustian, 2001, Rahasia Sukses Membangun Kecerdasan Emosi dan Spiritual (ESQ), Arga Wijaya Persada, Jakarta Azwar, 1997, Reliabilitas dan Validitas, Liberty, Yogyakarta Chakraborty, S.K, and Chakraborty, D, 2004, The Transformed Leader and Spiritual Psychology : A Few Insight, Journal of Organizational Change Management, Vol.17, No.2, pp.184-210 Chermiss, C, 1998, Working With Emotional Intelligence, The Consortium

For Research On Emotional Intelligence in Organizations, Rugrets University, New Jersey

Eysenck, H.J, and Kamin, L, 1981, Intelligence : The Batle For The Mind, PanBook, London dan Sydney

Evren Ayranci, Pengaruh Top Manajer Terhadap Kecerdasan Emosional

Spiritual Pada Kinerja Keuangan Organisasi, tahun, penerbit \& kota 2002, Tes IQ Anda, CV. Pionir Jaya, Bandung

Dwijayanti, P. 2009. Pengaruh Kecerdasan Emosional, Kecerdasan Intelektual, Kecerdasan Spiritual, dan Kecerdasan Sosial terhadap Pemahaman Akuntansi. Skripsi Fakultas Ekonomi Universitas Pembangunan Nasional Veteran. Jakarta.

Goleman, D, 2000, Kecerdasan Emosi : Mengapa Emotional Intelligence Lebih Tinggi Daripada IQ, Alih Bahasa : T. Hermay, PT. Gramedia Pustaka Utama, Jakarta

Goleman, Daniel. 2003. Emotional Intelligence. Jakarta: PT Gramedia Pustaka

Utama.

Gordon, E, 2004, EQ dan Kesuksesan Kerja, Focusonline,http://www.e- psikologi.com, 12 Desember 2004

Joseph, G, 1978, Interpreting Psychological Test Data, Vol.1, New York VNR

Mudali, 2002, Quote : How High Is Yous Spiritual Intelligence ?http://www.eng.usf.edu/gopalakr/artcles/spiritual.html, 15 Juni 2005

Muhammad Idrus, 2002, Kecerdasan Spiritual Mahasiswa 
Yogyakarta, Psikologi Phronesis, Jurnal Ilmiah dan Terapan, Vo.4, No.8, Desember 2002

Ningky Munir, 2000, Spiritualitas dan Kinerja, Majalah

Manajemen,Vol.124,Juli2000

Pratiwi, Dianny. 2011. Pengaruh Kemampuan Pemakai Tegnologi

Informasi, Kecerdasan Intelektual, Kecerdasan Emosional,

Kecerdasan Spiritual Terhadap Kinerja Karyawan, Tidak diterbitkan.

Jember. Skripsi Fakultas Ekonomi Universitas Jember.

Purwanto, Ngalim. 2003. Psikologi Pendidikan, PT Remaja Rosdakarya, Bandung.

Rahmi, A. (2008). Kecerdasan Emosional Dan Kehidupan Dunia Kerja. $7 /{ }^{1} P M-$, 11(1). Jakarta.

Robbins, S, P, 1996, Perilaku Organisasi, PT. Prehallindo, Jakarta

Rio Marpaung \& Citra Rumondang 2007, Pengaruh Kecerdasan Interlektual, Kecerdasan Emosi dan Kecerdasan Spiritual Terhadap Kinerja Karyawan, Pekan Baru.

Trihandini, M. F. 2005. Analisi Pengaruh Kecerdasan Intelektual, Kecerdasan Emosional dan Kecerdasan Spiritual Terhadap Kinerja Karyawan, Tesis, Fakultas Ekonomi Universitas Diponegoro, Semarang.

Wiersma, M.L, 2002, The

Influence of Spiritual "Meaning-Making" On Career

Behaviour, Journal of Management Development, Vo.21, No.7, pp.497-520

Widodo, S. (2012). Cara Baru Memberdayakan Diri Untuk Lebih Cepat Bahagia, Sukses, Dan Sejahtera. Jakarta: PT. Gramedia Pustaka Utama.

Yuninigsih, 2002, Membangun Komitmen dan Menciptakan Kinerja Sumber Daya Manusia Untuk Memperoleh Keberhasilan Perusahaan, Fokus Ekonomi Vol.1

No.1 April 2002

Zohar, D, Marshal, I, 2000, SQ (Spiritual Intelligence) : The Ultimate Intelligence, Blomsburry Publishing, London

Media Utama, Bandung 2001, The Ultimate Intelligence, Mizam Intelligence. Alih Bahasa Rahmani Astuti dkk., Bandung: Penerbit Mizan Media Utama. 